\title{
PREPARATION OF DIFFERENT CRUDE EXTRACT AND ANTIMICROBIAL STUDIES OF SPIROGYRA RHIZOPUS
}

\author{
DANIEL $E^{1}$, GIRMA $T^{1}$, VENKATESAN JAYAKUMAR $S^{2 *}$ \\ ${ }^{1}$ Department of Chemistry, College of Natural Sciences, Jimma University, Jimma, Ethiopia, ${ }^{2}$ Department of Chemistry, Shri Vaishnav \\ Vidyapeeth Vishwavidyalaya University, Indore, Madhya Pradesh, India. \\ Email: svjayakumar1970@gmail.com \\ Received: 16 April 2019, Revised and Accepted: 29 May 2019
}

ABSTRACT

Objective: The importance of this work is to prepare the crude extracts of Spirogyra rhizopus and to study the biological activity of crude extract against four bacterial strains.

Materials and Methods: Spirogyra algae collected from Jimma town, and crude extracts were prepared by cold percolation method and sonication method and further analyzed for qualitative phytochemical analysis. The efficacy of crude extracts is tested for bacterial activity by disc-diffusion method.

Results: The maximum zone of inhibition shown by the crude extract is compared to standard and control. Among the four extracts, chloroform extract displayed the promising inhibitory action against four bacterial strains.

Conclusions: The preliminary study concludes that green algae $S$. rhizopus is a potential source of pharmacologically active lead molecules. In vitro screening of crude extracts of green algae S. rhizopus shows promising activity against bacterial strains and thus suggests its application in drug discovery research.

Keywords: Spirogyra rhizopus, Ultrasound, Cold percolation, Phytochemical analysis, Antibacterial activity.

(C) 2019 The Authors. Published by Innovare Academic Sciences Pvt Ltd. This is an open access article under the CC BY license (http://creativecommons. org/licenses/by/4. 0/) DOI: http://dx.doi.org/10.22159/ajpcr.2019.v12i7.33627

\section{INTRODUCTION}

The medicinal plants are useful for the treatment of human diseases due to the presence of active phytochemical principles [1-6], and they have the advantage for an organism to serve as a chemical defense against predation $[7,8]$. Algae of marine and terrestrial origins have been significant attraction as source of bioactive molecules [9], and they can produce antibacterial [10], antifungal [11], and antiviral [12] compounds of interest for the drug discovery research program $[13,14]$. The phytochemical and pharmacological studies on algae prove that they are potential source of amino acids, terpenoids, phlorotannins, steroids, phenolic compounds, halogenated ketones, alkenes, and cyclic polysulfides [15]. Recent studies on algae showed that it can be useful for the bioremediation of heavy metals, and their ability to accumulate, tolerate high level of metals has been demonstrated [16]. Moreover, algae are one of the most promising sources of renewable biomass [17], for the production of biodiesel [18] and also can able to enrich the soil fertility [19].

Spirogyra species is a freshwater, and filamentous green algae contain high amount of nutritional compositions, which consumed as food in northern Thailand and have pharmacological properties. It contains high amounts of protein, carbohydrate, fat, dietary fiber [20], and mineral substances [21,22]. Amornlerdpison et al. reported that the crude extract of Spirogyra spp. has potential to inhibit the gastric ulcer formation induced under physical, chemical stress in rats, also displayed anti-inflammatory effect [23], and the recent research on Spirogyra spp. shows that the hypolipidemic and hypoglycemic abilities in rats induced by streptozotocin [24]. The in vitro studies of crude extract display antioxidant activity [25] and its phytochemical composition revealed the presence of phenolics, tannins, glycosides, and saponins [26].

However, there is no previous report on the preparation of crude extract of Spirogyra rhizopus and antibacterial activity studies of different solvent crude extracts. Hence, the focus of the present study is to carry out phytochemical qualitative analysis of crude extracts of Spirogyra species and study on antimicrobial activities of different crude extract. These tests were carried out following standard procedures reported in literature.

\section{MATERIALS AND METHODS}

Sample collection: Fresh Spirogyra spp. sample was collected from Kito around Jimma. The collected species were identified as $S$. rhizopus by the plant taxonomist in the Department of Life Sciences, Jimma University, Ethiopia.

Ultrasound for extraction is generated with the help of ultrasonic instrument. The specifications, operating parameters, and the details are as follows. Designed and made by China, operating frequency: $36 \pm 3 \mathrm{kHz}$; rated output power: $700 \mathrm{~W}$; and tank size: $240 \mathrm{~mm} \times 135 \mathrm{~mm} \times 100 \mathrm{~mm}$.

\section{Preparation of crude extracts}

The fresh S. rhizopus was washed under tap water and distilled water to remove associated debris, dried under shade, and further grounded into fine powder using electric blender. The method of preparation of crude extract as described below.

\section{Sequential solvent extraction of $S$. rhizopus}

The procedure of preparing crude extracts of the S.rhizopus was conducted in accordance with reported method [27]. Extraction was carried out at room temperature under normal condition by maceration technique also called as cold percolation method. The dry powder was weighed accurately and subjected to extraction in an orbit shaker apparatus with solvent in the sequential order of increasing polarity as petroleum ether, chloroform, acetone, and methanol successively for $72 \mathrm{~h}$ with constant continuous shaking. Before carry on the extraction with the next solvent, residue was air dried to remove the adhering solvent, and the same procedure was followed. 
Sequential extraction by petroleum ether, chloroform, acetone, and methanol

Dried and powdered material of S. rhizopus was subjected to sequential solvent extraction with petroleum ether, chloroform, acetone, and methanol using maceration technique, and antibacterial studies were carried out using in vitro method. About $300 \mathrm{~g}$ dry powder of $S$. rhizopus was soaked in $1000 \mathrm{ml}$ of petroleum ether in airtight conical flask for $72 \mathrm{~h}$ on an orbit shaker and filtered, and filtrates were collected into airtight bottles. The same procedure was followed with fresh petroleum ether; the filtrates were pooled together; the solvent was distilled under vacuum by rotary evaporator; and the resulting crude extract was stored in deep freezer $\left(-20^{\circ} \mathrm{C}\right)$ until further study. The residue of the algal powder was dried and used for further sequential, gradient extractions with an equal volume of chloroform, acetone, and methanol; the same procedure was followed; and different crude extracts were prepared, the results are displayed in Table 1.

Twenty gram of dry, powdered S. rhizopus sample was taken and sequentially extracted with different solvents (petroleum ether, chloroform, acetone, and methanol) using ultrasonic instrument (45 kHz, $210 \mathrm{kHz}$, and $1 \mathrm{MHz}$ ). The weight of the crude extracts and their percent yields by sonication method are given in Table 2 .

Comparison of the yield of crude extract by maceration and sonication method

The influence of ultrasound radiation on the yield of extraction with various solvents was studied, and influence on yield is negligible. However, in microwave method, violent eruption of solvent was observed even under low intensity of microwave irradiation.

\section{Phytochemical analysis}

The extracts were subjected to phytochemical tests to confirm the presence of biomolecules using standard qualitative procedures as described in literature [28], and the results are presented in Table 3.

\section{Antibacterial activity studies}

\section{Procedure of antibacterial test of algae extracts}

For testing the antibacterial activity of different solvent crude extracts, the following bacterial strains Staphylococcus aureus, Escherichia coli,

Table 1: Amounts of crude extracts obtained by cold percolation method

\begin{tabular}{lll}
\hline Solvents & Mass of crude extract (g) & \%yield \\
\hline Petroleum ether & 4.227 & 1.409 \\
Chloroform & 10.405 & 3.468 \\
Acetone & 5.748 & 1.916 \\
Methanol & 5.437 & 1.812 \\
\hline
\end{tabular}

Table 2: Amounts of crude extracts obtained by ultrasound assisted extraction method

\begin{tabular}{lll}
\hline Solvents & Mass of crude extract (g) & \%yield \\
\hline Petroleum ether & 0.380 & 1.9 \\
Chloroform & 0.7668 & 3.83 \\
Acetone & 0.446 & 2.23 \\
Methanol & 0.428 & 2.14 \\
\hline
\end{tabular}

Pseudomonas aeruginosa, and Salmonella typhimurium were obtained from the Microbiology Department, Addis Ababa University, Addis Ababa, Ethiopia. The bacterial culture of E. coli, P. aeruginosa, $S$. typhimurium, and $S$. aureus was pre-cultured in nutrient broth. The media were incubated overnight at $35^{\circ} \mathrm{C}$ in rotary shaker and it was centrifuged at 10,000 rpm for about $5 \mathrm{~min}$. The pellet was suspended in distilled water, and the turbidity was compared with 0.5 McFarland standards to ensure the suspension approximately $10^{8} \mathrm{cfu} / \mathrm{ml}$. The activity was tested using disc-diffusion method [29], prior to that bacterial suspension was spread evenly onto the Muller Hilton Agar plates by using sterile cotton swab. The solvent crude extracts of algae samples were tested in a dose level of $100 \mathrm{mg} / \mathrm{ml}$, and the medium in the plates was allowed to set at room temperature for 10-20 min at room temperature for the diffusion of the extract into the agar and finally, incubated at $35^{\circ} \mathrm{C}$ for $24 \mathrm{~h}$ for bacterial growth. After incubation, the antibacterial activity was indicated by a clear zone of inhibition and measured with the help of a ruler and the results are displayed in Table 4. Dimethyl sulfoxide (DMSO) will be used as negative control against all the bacterial pathogens, and gentamycin was used as positive control for S. aureus, E. coli, P. aeruginosa, and S. typhimurium.

\section{Evaluation of antibacterial effects with agar disc diffusion} method

Whatman No.3 filter paper (sterilized) disks (6 $\mathrm{mm}$ in diameter) was placed onto the surface of inoculated Petri dishes, and the $S$. rhizopus crude extracts (petroleum ether, chloroform, acetone, and methanol) were dissolved in DMSO and were placed separately on the inoculated Petri dishes. In brief, the extract disc contained $100 \mu \mathrm{l}$ of extract, positive control disc contained gentamycin $(10 \mu \mathrm{g} / \mathrm{disc})$, and the negative control disc contained $100 \mu \mathrm{l}$ of DMSO. The Petri dishes were then allowed for 10-20 $\mathrm{min}$ at room temperature for the diffusion of the extract into the agar and finally, incubated at $30^{\circ} \mathrm{C}$ for $24 \mathrm{~h}$ for bacterial growth. The antibacterial activity was indicated by a clear zone of inhibition and measured with the help of a ruler, and the results are displayed in Table 4 and zone of inhibition shown in Fig. 1. diameters of inhibitory zones induced by the extracts were interpreted as follows: resistant (12 $\mathrm{mm}$ or less), intermediate (13-15 $\mathrm{mm}$ ), and susceptible (16 $\mathrm{mm}$ or above), followed the standard. MIC values were determined as the lowest concentration that completely inhibited the growth of bacteria after $24 \mathrm{~h}$ of incubation at $29^{\circ} \mathrm{C}$ for $24 \mathrm{~h}$.

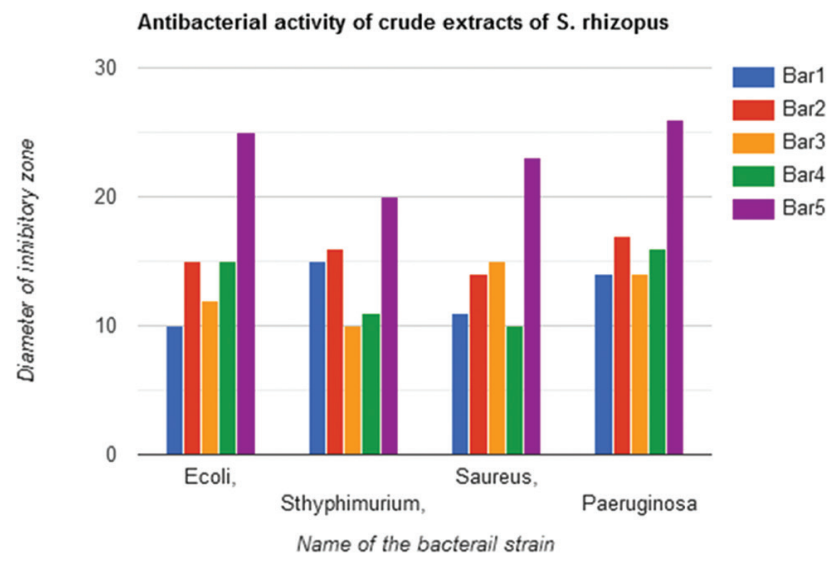

Table 3: Phytochemical screening of Spirogyra spp. extracts of different solvents

\begin{tabular}{lllll}
\hline Phytochemical & Petroleum ether & Chloroform & Acetone & Methanol \\
\hline Alkaloid & - & - & - & - \\
Terpene & + & + & + & - \\
Tannin & - & + & + & + \\
Saponin & - & + & + & + \\
Flavonoid & - & - & - & + \\
Anthraquinone & - & - & + & - \\
\hline
\end{tabular}

- sign confirms the absence of particular phytochemical and + sign shows that presence of particular phytochemical in the crude extract 
Table 4: Antibacterial activity of Spirogyra rhizopus crude extracts of different solvents

\begin{tabular}{lllll}
\hline Solvent & Escherichia coli & Salmonella typhimurium & Staphylococcus aureus & Pseudomonas aeruginosa \\
\hline Petroleum ether & 10 & 15 & 11 & 14 \\
Chloroform & 15 & 16 & 14 & 17 \\
Acetone & 12 & 10 & 15 & 14 \\
Methanol & 15 & 11 & 10 & 16 \\
Gentamicin* & 25 & 20 & 23 & 26 \\
DMSO*,\# & - & - & - & - \\
\hline
\end{tabular}

Values are in $\mathrm{mm} ;{ }^{*}(+)$ ve control; ${ }^{* *}(-)$ ve control, No inhibition zone. DMSO: Dimethyl sulfoxide

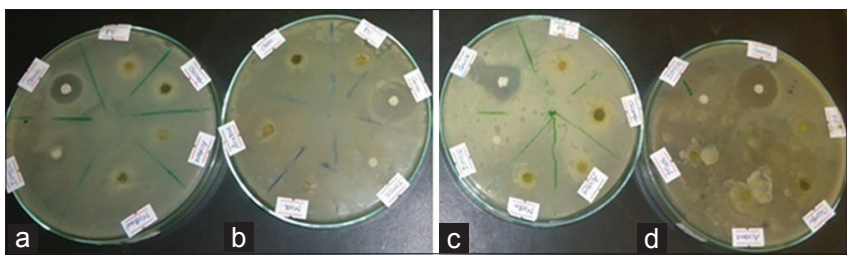

Fig. 1: (a-d) Antibacterial activity of Spirogyra rhizopus crude extracts of different solvents. (a) Salmonella thyphiurium, (b) Pseudomonas aeruginosa, (c) Staphylococcus aureus, (d) Escherichia coli

X-axis: Bacterial strain; Y-axis: Zone of inhibition ( $\mathrm{mm}$ ) and each bar is crude extract; Name of the crude extracts: Bar 1: Petroleum ether; Bar 2: Chloroform; Bar 3: Acetone; Bar 4: Methanol; Bar 5: Gentamicin

\section{RESULTS AND DISCUSSION}

\section{Antibacterial activity studies of $S$. rhizopus}

Evaluation of antibacterial activity for different solvent crude extracts was carried out by standard procedure. The petroleum ether, chloroform, acetone, and methanol extracts of $S$. rhizopus were tested against four bacterial pathogens S. typhimurium, P. aeruginosa, S. aureus, and E. coli, the results are presented in Table 3 , and the degree of activity was varied with reference to different solvent extracts of $S$. rhizopus; from table, chloroform extracts were found to show the maximum zone of inhibition against S. typhimurium and P. aeruginosa. The acetone extract showed maximum zone of inhibition against $P$. aeruginosa and $S$. aureus, followed by $E$. coli. The petroleum ether extract showed maximum zone of inhibition against S. typhimurium, followed by P. aeruginosa. The methanol extract showed maximum zone of inhibition against $P$. aeruginosa followed by E. coli.

\section{CONCLUSIONS}

Extensive efforts for the identification of bioactive compounds derived from natural resources have been made worldwide, to develop safe, nontoxic, and efficient antimicrobial agents of valuable practice in pharmacology. The present study concludes that green algae S. rhizopus is a rich and varied source of pharmacologically active natural products. In vitro screening of organic solvent extracts of green algae $S$. rhizopus shows promising activity against bacterial strains. Among all the organic extracts chloroform crude extract showed excellent effect of bacterial inhibition. Further column chromatography isolation of lead molecules, characterization, and bioactivity studies will publish in the due course of time.

\section{ACKNOWLEDGMENT}

We are grateful to the Ministry of Higher Education and Research, Ethiopia, for the research funding. We express our sincere thanks to Dr. Jemal Abafita, President of Jimma University for the constant encouragement and we also thank Gemechis File, Dean, College of Natural Sciences, Jimma University and University of Addis Ababa, Ethiopia, for providing the chemicals and solvents and for spectral data.

\section{AUTHORS' CONTRIBUTIONS}

Collection of S. rhizopus (algae) material from Jimma town, park, lake, and ponds: Daniel, venkatesan jayakumar, Jimma University.
Identification and processing of the collected Spirogyra algae: Nair, Taxonomist, Department of Life Science, Jimma University.

Design and Preparation of solvent crude extracts, phytochemical analysis: Girma, Venkatesan jayakumar, Daniel, Jimma University.

Collection of bacterial strain, antibacterial assay and statistical analysis: Birtukan, Department of Microbiology, University of Addis Ababa, Daniel, Venkatesan jayakumar, Jimma University.

Writing original draft, review and editing: Girma, Venkatesan jayakumar, Jimma University.

\section{CONFLICTS OF INTEREST}

No conflict of interest and the authors authenticate that there are no known conflicts of interest affiliated with this publication and there has been no significant financial support for this work that could have influenced its outcome.

\section{REFERENCES}

1. Sarker SD, Latif Z, Gray AI. Natural Products Isolation. $2^{\text {nd }}$ ed. New Jersey: Humana Press Totowa; 2006. p. 1-20.

2. Newman DJ, Cragg GM. Natural products as source of new drugs over the 30 years from 1981 to 2010 . J Nat Prod 2012;75:311-35.

3. Newman DJ, Cragg GM, Snader KM. The influence of natural products upon drug discovery. Nat Prod Rep 2000;17:215-34.

4. Kinghorn AD. Pharmacognosy in the $21^{\text {st }}$ century. J Pharm Pharmacol 2001;53:135-48.

5. Buss AD, Cox B, Waigh RD. Drug discovery. In: Burger's Medicinal Chemistry and Drug Discovery. Vol. 1. Ch. 20. New Jersey: Wiley, Hoboken; 2003. p. 847-900.

6. Lagunin A, Filimonov D, Poroikov V. Multi-targeted natural products evaluation based on biological activity prediction with PASS. Curr Pharm Des 2010;16:1703-17.

7. Clardy J, Walsh C. Lessons from natural molecules. Nature 2004;432:829-37.

8. De Lara-Isassi G, Alvarez-Hernandez S, Collado-Vides L. Ichtyotoxic activity of extracts from Mexico-marine macroalgae. J Appl Phycol 2000;12:45-52.

9. Bhakuni DS, Rawat DS. Bioactive Marine Natural Products. New Delhi, India: Springer-Verlag; 2005. p. 404-52.

10. Goud ML, Seshika AD, Charya MA. Antibacterial activity and biomolecular composition of certain freshwater microalgae from river godavari (India). Sci World J 2007;2:19-23.

11. Tang HF, Yang-Hua Y, Yao XS, Xu QZ, Zhang SY, Lin HW. Bioactive steroids from the brown alga Sargassum carpophyllum. J Asian Nat Prod Res 2002;4:95-101.

12. Taskin E, Ozturk M, Taskin E, Kurt O. Antibacterial activities of some marine algae from the aegean sea (Turkey). Afr J Biotechnol 2007;6:2746-51.

13. Serkedjieva J. Antiviral activity of the red marine alga Ceramium rubrum. Phytother Res 2004;18:480-3.

14. Tuney I, Cadirci B, Unal D, Sukatar A. Antimicrobial activities of the extracts of marine algae from the coast of Urla (Izmir, Turkey). Turk J Biol 2006;30:171-5.

15. Patra JK, Rath SK, Jena K, Rathod VK, Thatoi HN. Evaluation of antioxidant and antimicrobial activity of seaweed (Sargassum sp.) extract: A study on inhibition of glutathione-stransferase activity. Turk J Biol 2008;32:119-25.

16. Yu Q, Matheickal JT, Yin P, Kaewsarn P. Heavy metal uptake capacities 
of common marine macroalgal biomass. Water Res 1999;33:1534-7.

17. Farias S, Arisnabarreta SP, Smichowski P. Levels of essential and potentially toxic trace metals in Antarctic macro algae. Spectrochim Acta Part B 2002;57:2133-40.

18. Sudhakar K, Rajesh M, Premalatha M. A mathematical model to assess the potential of algal bio-fuels in India. Energy Sources Part A 2012;34:1-7.

19. Heydarzadeh JK, Amini MA, Khalizadeh M, Pazouki AA, Ghoreyshi M, Najafpour GD. Esterification of free fatty acids by heterogeneous alumina-zirconia catalysts for biodiesel synthesis. World Appl Sci J 2010;9:1306-12.

20. Mitova MI, Usov AL, Bilan MI, Stefanov KL, DimitrovaKonaklieva SD, Tonov DP, et al. Sterols and polysaccharides in freshwater algae Spirogyra and Mougeotia Zeit. Nat C 1999;54:1016-20.

21. Phinyo K, Khanongnuch C, Pekkoh J, Pumas C, Peerapornpisal Y. Nutritional Values and Polysaccharides in Tao (Spirogyra neglecta (Hassall) Kützing) from Phare Province Proceeding, The $2^{\text {nd }}$ MJUPhrae National Research Conference; 2012. p. 50-6.

22. Peerapornpisal Y. Edible freshwater macroalgae in northern Thailand. Fish Sci J 2007;1:178-88.
23. Amornlerdpison D, Duangjun K, Kanjanapothi D, Peerapornpisal Y. Gastroprotective activity of Spirogyra neglecta (Hassall) Kutzing. KKU Sci J 2012;40:236-41.

24. Lailerd N, Pongchaidecha A, Amornlerdpison D, Peerapornpisal Y Beneficial effects of Spirogyra neclecta (Hassall) extract on glycemic and lipidemic status in streptozotocin-induced diabetic rats with enriched fat. Ann Nutr Metab 2009;55:709-16.

25. Peerapornpisal Y, Punyoyai T, Amormledpison D. Antioxidant and antiinflammatory activities of Spirogyra neglecta (Hassall) Kutzing. KKU Sci J 2012;40:228-35.

26. Sofowara A. Medicinal Plants and Traditional Medicine in Africa. $2^{\text {nd }}$ ed. Sunshine house Ibadan: Nigeria: Spectrum Books Ltd.; 1993. p. 81-93.

27. Jones WP, Kinghorn AD. Natural product isolation: Extraction of plant secondary metabolites. Methods Biotechnol 2005;20:323-51.

28. Bauer AW, Kirby WM, Sherris JC, Turck M. Antibiotic susceptibility testing by a standardized single disk method. Am J Clin Pathol 1966;45:493-6.

29. Ansari N, Hemavani C, Thippeswamy B. Evaluation of antimicrobial property of Spirogyra species. Int Multidiscip Res J 2012;2:13-5. 